\title{
Lessons from Schumpeterian Growth Theory
}

\section{Citation}

Aghion, Philippe, Ufuk Akcigit, and Peter Howitt. 2015. "Lessons from Schumpeterian Growth Theory." American Economic Review 105 (5): 94-99. https://doi.org/10.1257/aer.p20151067.

\section{Permanent link}

http://nrs.harvard.edu/urn-3:HUL.InstRepos:41555793

\section{Terms of Use}

This article was downloaded from Harvard University's DASH repository, and is made available under the terms and conditions applicable to Other Posted Material, as set forth at http:// nrs.harvard.edu/urn-3:HUL.InstRepos:dash.current.terms-of-use\#LAA

\section{Share Your Story}

The Harvard community has made this article openly available.

Please share how this access benefits you. Submit a story.

Accessibility 


\title{
Lessons from Schumpeterian Growth Theory
}

\author{
By Philippe Aghion, Ufuk Akcigit, And Peter Howito*
}

\section{Introduction}

Formal models allow us to make verbal notions operational and confront them with data. Schumpeterian growth theory ${ }^{1}$ has "operationalized" Schumpeter's notion of creative destruction -the process by which new innovations replace older technologies-, in two ways. First, it has developed models based on creative destruction that shed new light on several microeconomic aspects of the growth process: in particular on the role of competition, on firm dynamics and on cross-firm and cross-sector reallocation. Second, it has used rich micro data, in particular on entry, exit and firm size distribution to confront predictions that distinguish it from other growth theories. In both respects, Schumpeterian growth theory has helped bridge the gap between micro and macroeconomics.

In this paper, we consider three aspects on which Schumpeterian growth theory delivers distinctive predictions: first, the relationship between growth and market power; second, the relationship between growth and firm dynamics; third, the relationship between growth and development. $^{2}$

\section{Aghion-Howitt (1992) in a nutshell}

The Schumpeterian growth model is based on three main ideas: (i) it is about growth generated by innovations; (ii) innovations result from

\footnotetext{
* Aghion: Harvard University, Dept of Economics, Littauer Center 222, Cambridge, MA 02138, paghion@fas.harvard.edu. Akcigit: University of Pennsylvania, Dept of Economics, 3718 Locust Walk, McNeil 160, Philadelphia PA 19104, uakcigit@econ.upenn.edu. Howitt: Brown University, Dept of Economics, Robinson Hall, 64 Waterman Street, Providence, RI 02912, Peter_Howitt@brown.edu.

${ }^{1}$ The theory was initiated in the fall of 1987 at MIT. During that year Aghion and Howitt wrote their "model of growth through creative destruction" (see Section II below) which came out in print as Aghion and Howitt (1992). Parallel attempts at developing Schumpeterian growth models, include Segerstrom, Anant and Dinopoulos (1990) and Corriveau (1991).

${ }^{2}$ See Grossman and Helpman (1991) for a discussion of the parallels between the Schumpeterian and product variety models. Here we focus instead on the differences between the two approaches.
}

entrepreneurial investments that are themselves motivated by the prospects of monopoly rents; and (iii) new innovations replace old technologies: in other words, growth involves creative destruction.

More formally, in the basic Aghion-Howitt model time is continuous and the economy is populated by a continuum of mass $L$ of individuals. Individuals are risk-neutral and each individual is endowed with one unit flow of labor per unit of time, which she can devote either to manufacturing or to research and development (R\&D),

A final output is produced at any time using an intermediate input, according to:

$$
Y=A y^{\alpha},
$$

where $A$ denotes the current quality of the input, which is multiplied by a factor $\gamma>1$ each time a new innovation occurs. Innovations arrive at Poisson rate $\lambda z$, where $z$ is the amount of labor devoted to R\&D.

The intermediate is itself using labor "one for one", thus $y$ also denotes the amount of labor working in manufacturing the intermediate input.

The model revolves around two basic equations. First, the labor market clearing equation:

$$
y+z=L,
$$

where $L$ denote total labor supply. Second, a research arbitrage equation which says that in equilibrium, an individual is indifferent between working in $R \& D$ or in manufacturing, namely:

$$
w_{k}=\lambda V_{k+1}
$$

where $w_{k}$ is the wage rate paid by the intermediate input sector after the $k^{\text {th }}$ innovation, and $V_{k+1}$ is the value of the next - i.e. the $(k+1)^{t h}$ innovation. $^{3}$

\footnotetext{
${ }^{3}$ If innovating gave the innovator access to a permanent profit flow $\pi_{k+1}$, then the value of the corresponding perpetuity would be $\pi_{k+1} / r$. However, there is creative destruction at aggregate
} 
These two equations allow us to determine the equilibrium $R \& D$ using equations (L) and (R). The resulting equilibrium aggregate $R \& D$ $z$ depends upon the parameters of the economy. In particular, a higher productivity of the $\mathrm{R} \& \mathrm{D}$ technology as measured by $\lambda$ or a larger size of innovations $\gamma$ or a larger size of the population $L$ has a positive effect on aggregate $R \& D$. On the other hand a higher $\alpha$ (which corresponds to the intermediate producer facing a more elastic inverse demand curve and therefore getting lower monopoly rents) or a higher discount rate $\rho$ tends to discourage $\mathrm{R} \& \mathrm{D}$.

Finally, the expected growth rate

$$
\mathbb{E}\left(g_{t}\right)=\lambda z \ln \gamma,
$$

inherits the comparative static properties of $z$ with respect to the parameters $\lambda, \gamma, \alpha, \rho$, and $L$.

A distinct prediction of the model is:

Prediction 1: The turnover rate $\lambda z$ is positively correlated with the growth rate $g$.

Another distinctive implication of the model is that innovation-led growth may be excessive under laissez-faire. Growth is excessive (resp. insufficient) under laissez-faire when the business-stealing effect associated with creative destruction dominates (resp. is dominated by) the intertemporal knowledge spillovers from current to future innovators. ${ }^{4}$

\section{Growth meets IO}

Both, empirical studies ${ }^{5}$ and casual evidence point to a positive correlation between growth and product market competition which is at odds with what most endogenous growth models predict.

However one can reconcile theory with evidence by allowing for step-by-step innovation in the Schumpeterian growth model. ${ }^{6}$ Namely, a firm that is currently behind the technological

rate $\lambda z$. As a result, we have: $V_{k+1}=\frac{\pi_{k+1}}{\rho+\lambda z}$. That is, the value of innovation is equal to the profit flow divided by the risk-adjusted interest rate $\rho+\lambda z$ where the risk is that of being displaced by a new innovator.

${ }^{4}$ Which of these effects dominates will depend in particular upon the size of innovations. Assessing the relative importance of these two effects in practice, requires estimating the structural parameters of the growth model using micro data (see footnote 9).

\footnotetext{
${ }^{5}$ E.g. see Blundell, Griffith and Van Reenen (1995).

${ }^{6}$ See Aghion, Harris and Vickers (1997) and Aghion, Harris, Howitt and Vickers (2001).
}

leader in the same sector or industry must catch up with the leader before becoming a leader itself. This step-by-step assumption implies that firms in some sectors will be neck-and-neck. In turn in such sectors, increased product market competition, by making life more difficult for neck-and-neck firms, will encourage them to innovate in order to acquire a lead over their rival in the sector. This we refer to as the escape competition effect. On the other hand, in unleveled sectors where firms are not neck-and-neck, increased product market competition will tend to discourage innovation by laggard firms as it decreases the short-run extra profit from catching up with the leader. This we call the Schumpeterian effect. Finally, the steady-state fraction of neck-and-neck sectors will itself depend upon the innovation intensities in neck-and-neck versus unleveled sectors. This we refer to as the composition effect.

The Schumpeterian growth framework with step-by-step innovation, generates three interesting predictions:

Prediction 1: The relationship between competition and innovation follows an inverted- $U$ pattern.

Intuitively, when competition is low, innovation intensity is low in neck and neck sectors, therefore most sectors in the economy are neck and neck (the composition effect); but precisely it is in those sectors that the escape competition effect dominates. Thus overall aggregate innovation increases with competition at low levels of competition. When competition is high, innovation intensity is high in neck and neck sectors, therefore most sectors in the economy are unleveled sectors, so that the Schumpeterian effect dominates overall. This inverted- $\mathrm{U}$ prediction is confirmed by Aghion, Bloom, Blundell, Griffith and Howitt (2005), ABBGH, using panel data on UK firms.

Prediction 2: More intense competition enhances innovation in "frontier" firms but may discourage it in "non-frontier" firms.

Intuitively, a frontier firm can escape competition by innovating, unlike a non-frontier firm who can only catch up with the leader in its sector. This prediction is tested by Aghion, Blundell, Griffith, Howitt and Prantl (2009) using again panel data of UK firms.

Prediction 3: There is complementarity between patent protection and product market 
competition in fostering innovation.

Intuitively, competition reduces the profit flow of non-innovating neck-and-neck firms, whereas patent protection is likely to enhance the profit flow of an innovating neck-and-neck firm. Both contribute to raising the net profit gain of an innovating neck-and-neck firm; in other words, both types of policies tend to enhance the escape competition effect. ${ }^{7}$ This prediction is confirmed by Aghion, Howitt and Prantl (2013) using OECD country-industry panel data.

\section{Schumpeterian growth and firm dynamics}

The empirical literature has documented various stylized facts on firm size distribution and firm dynamics using micro firm-level data. In particular: $(i)$ the firm size distribution is highly skewed; ( $i$ i) firm size and firm age are highly correlated; (iii) small firms exit more frequently, but the ones that survive tend to grow faster than the average growth rate.

These are all facts that non-Schumpeterian growth models cannot account for. In particular, the first four facts listed require a new firm to enter, expand, then shrink over time, and eventually be replaced by new entrants: these and the last fact on the importance of reallocation are all embodied in the Schumpeterian idea of creative destruction.

Instead the Schumpeterian model by Klette and Kortum (2004) can account for these facts. This model adds two elements to the baseline model: first, innovations come from both entrants and incumbents; second, firms are defined as a collection of production units where successful innovations by incumbents will allow them to expand in product space. ${ }^{8}$

This model allows us to explain the above stylized facts:

\footnotetext{
${ }^{7}$ That competition and patent protection should be complementary in enhancing growth rather than mutually exclusive is at odds with Romer's (1990) product variety model, where competition is always detrimental to innovation and growth (as we discussed above) for exactly the same reason that intellectual property rights (IPRs) in the form of patent protection are good for innovation: namely, competition reduces post-innovation rents, whereas patent protection increases these rents. See Acemoglu and Akcigit (2012) for a general analysis of optimal patent protection in Schumpeterian models with step-by-step innovation.

${ }^{8}$ Various versions of this framework have been estimated using micro-level data by Lentz and Mortensen (2008), Acemoglu, Akcigit, Bloom and Kerr (2013), Akcigit and Kerr (2014) and Garcia-Macia, Hsieh and Klenow (2014).
}

Prediction 1: The size distribution of firms is highly skewed.

Recall that in this model, firm size is summarized by the number of product lines of a firm. Hence, a firm needs to have succeeded many attempts to innovate in new lines and at the same survived many attempts by potential entrants and other incumbents at taking over its existing lines, in order to become a large firm. This is turn explains why there are so few very large firms in steady-state equilibrium, i.e. why firm size distribution is highly skewed as shown in a vast empirical literature.

Prediction 2: Firm size and firm age are positively correlated.

In the model, firms are born with a size of 1 . Subsequent successes are required for firms to grow in size, which naturally produces a positive correlation between size and age. This regularity has been documented extensively in the literature. $^{9}$

Prediction 3: Small firms exit more frequently. The ones that survive tend to grow faster than average.

In the above model, it takes only one successful entry to make a one-product firm to exit, whereas it takes two successful innovations by potential entrants to make a two-product firm exit. The facts that small firms exit more frequently and grow faster conditional on survival have been widely documented in the literature. ${ }^{10}$

\section{Growth meets development}

The previous two sections have implications for how Schumpeterian growth theory can help bridge the gap between growth and development economics: first, by capturing the idea that growth-enhancing policies or institutions vary with a country's level of technological development; second, by analyzing how institutional development (or the lack of it) affects firm size distribution and firm dynamics.

\footnotetext{
${ }^{9}$ For recent discussions, see Haltiwanger, Jarmin and Miranda (2010) and Akcigit and Kerr (2010).

${ }^{10}$ See Aghion, Akcigit and Howitt (2014 a,b) and Akcigit and Kerr (2010) for references. In a recent work, Acemoglu, Akcigit, Bloom and Kerr (2013) analyze the effects of various industrial policies on equilibrium productivity growth, including entry subsidy and incumbent R\&D subsidy, in an enriched version of the above framework.
} 


\section{A. Appropriate institutions}

In Section 3 we mentioned some recent evidence for the prediction that competition and free-entry should be more growth-enhancing in more frontier firms, which implies that they should be more growth-enhancing in more advanced countries since those have a larger proportion of frontier firms. Similarly, Acemoglu, Aghion and Zilibotti (2006) show, using a crosscountry panel of more than 100 countries over the 1960-2000 period:

Prediction 1: Average growth should decrease more rapidly as a country approaches the world frontier when openness is low.

AAZ repeat the same exercise using entry costs faced by new firms instead of openness. They show:

Prediction 2: High entry barriers become increasingly detrimental to growth as the country approaches the frontier.

These two empirical exercises point to the importance of interacting institutions or policies with technological variables in growth regressions: openness is particularly growthenhancing in countries that are closer to the technological frontier; entry is more growthenhancing in countries or sectors that are closer to the technological frontier.

Next, to the extent that frontier innovation makes greater use of research education than imitation, the prediction is:

Prediction 3: The more frontier an economy is, the more growth in this economy relies on research education. ${ }^{11}$

Finally, one can look at the relationship between technological development, democracy and growth. An important channel is Schumpeterian: namely, democracy reduces the scope for expropriating successful innovators or for incumbents to prevent new entry by using political pressure or bribes: in other words, democracy facilitates creative destruction and thereby en-

\footnotetext{
${ }^{11}$ Aghion, Boustan, Hoxby and Vandenbussche (2009) show that research-type education is always more growth-enhancing in US states that are more frontier, whereas a bigger emphasis on two-year colleges is more growth-enhancing in US states that are farther below the productivity frontier. Similarly, using crosscountry panel data, Vandenbussche, Aghion and Meghir (2006) show that tertiary education is more positively correlated with productivity growth in countries that are closer to the world technology frontier.
}

courages innovation. ${ }^{12}$ To the extent that innovation matters more for growth in more frontier economies, the prediction is:

Prediction 4: The correlation between democracy and innovation/growth is more positive and significant in more frontier economies.

This prediction is confirmed by Aghion, Alesina and Trebbi (2007) using employment and productivity data at industry level across countries and over time.

\section{B. Innovation, institutions, and firm dynamics in developing countries}

Firm dynamics show massive differences across countries. In a recent work, Hsieh and Klenow (2014) show that while establishments grow 5 times relative to their entry size by the age of 30, Indian counterparts barely show any growth. Why do establishments do not grow in India? Bloom et al. (2013) have empirically shown that lack of trust and the weak rule of law is a major obstacle to firm growth.

What are the aggregate implications of the lack of delegation and weakness of rule of law on productivity and firm dynamics? To answer this question, Akcigit, Alp, and Peters (2014) extend the firm dynamics model introduced in the previous section, by adding two major ingredients: $(i)$ production requires managers and unless firm owners delegate some of the tasks, firms run into span of control problem as owners' time endowment is limited; (ii) firm owners can be of two types, high or low. High-type firms are more creative and have the potential of expanding much faster than low type firms. Whether this fast expansion is materialized or not depends on the return to expansion which itself depends on the possibility of delegation.

The predictions, both on the delegation margin and on the firm dynamics can be summarized as follows:

Prediction 1: Everything else equal, the probability of hiring an outside manager and, conditional on hiring, the number of outside managers is (i) increasing in firm size, (ii) decreasing in the owner's time, and (iii) increasing

\footnotetext{
${ }^{12}$ Acemoglu and Robinson (2006) formalize another reason, also Schumpeterian, as to why democracy matters for innovation: namely, new innovations do not only destroy the economic rents of incumbent producers, they also threaten the power of incumbent political leaders.
} 
in the rule of law.

Larger firms operate with more product lines and hence they have less time from the owner directly. Hence, the marginal contribution of an outside manager is much higher in larger firms. The second part relates the family size to delegation. If the owner has more time (due to larger family size, for instance), then the owner has already more time to invest in his business and this lowers the demand for outside managers. Finally stronger rule of law implies higher net return to delegation. AAP provide empirical support for these predictions using Indian manufacturing establishments.

Prediction 2: Average firm size: (i) increases in the owner's time, (ii) increases in the rule of law, and (iii) the positive relationship between firm size and the owner's time becomes weaker as the rule of law improves.

Firm value is increasing in owner time and therefore the firms are willing to innovate and expand more when firm value is higher. The empirical support for the first part is provided by Bloom et al (2013). The positive link between firm size and the rule of law has been extensively documented in the literature (See for instance Bloom, Sadun, and Van Reenen (2012) for a detailed discussion). Finally, AAP show that the link between firm size and family size is weaker in high trust regions in India.

Prediction 3: Firm growth decreases in firm size, more so when the rule of law is weaker.

This prediction follows from the fact that in larger firms, the owner has less time to allocate in each product line and hence the frictions to delegation become much more important for large firms. Hence, when the rule of law is weak, larger firms have less of an incentive to grow which means that the difference in growth incentives between large and small firms will be much more pronounced in weak rule of law countries or regions. AAP show that growth decreases faster in firm size in low trust regions in India.

Prediction 4: Everything else equal, creative destruction and reallocation among firms will be much higher in economies where the rule of law is stronger, thanks to the delegation possibilities.

Clearly this latter prediction is in line with the main findings of Hsieh and Klenow's work which showed the missing growth and reallocation in developing countries. Understanding the reasons behind the lack of reallocation and creative destruction is essential in designing the right development policies. The Schumpeterian growth framework provides a useful framework to conduct counterfactual policy exercises which can shed light on this important debate.

\section{Conclusion}

In this paper, we saw how Schumpeterian growth theory can generate distinctive predictions: (i) on growth and product market competition; (ii) on the dynamic patterns of markets and firms and on how these patterns shape the overall growth process. And we saw how it can reconcile growth with development: first, by bringing out the notion of appropriate growth institutions and policies; second, by looking at how institutional development shapes the relationship between firm size distribution, reallocation, and growth.

The Schumpeterian paradigm can be further explored in several interesting directions. One is to analyze the relationship between inequality and growth. ${ }^{13}$ Another is to look at innovationled growth and well-being. ${ }^{14}$ These and many other potential applications of the paradigm are left for future research.

*All references in this article can be found in Aghion, Akcigit, and Howitt (2014,2015).

\section{REFERENCES}

Aghion, Philippe, Ufuk Akcigit, and Peter Howitt. 2014. "What Do We Learn From Schumpeterian Growth Theory?" In Handbook of Economic Growth. Edited by P. Aghion and S. Durlauf. Vol. 2, 515-563. Amsterdam, Elsevier.

Aghion, Philippe, Ufuk Akcigit, and Peter Howitt. 2015. "The Schumpeterian Growth Paradigm," Annual Review of Economics, forthcoming.

\footnotetext{
${ }^{13}$ In particular innovation-led growth creates rents (which boosts top income shares) but it also involves creative destruction (which fosters social mobility). See Aghion, Akcigit, Bergeaud, Blundell and Hemous (2014).

${ }^{14}$ On the one hand more creative destruction implies more job destruction, which reduces the well-being of currently employed workers. On the other hand more creative destruction implies both, more new job creation and a higher growth rate, both of which are welfare-enhancing. See Aghion, Akcigit, Deaton and Roulet (2014).
} 